\title{
KIŞ, Salih (2017), Osmanlı Ordusunda Alman Ekolü Von Der Goltz Paşa (1883-1895), Konya: Palet Yayınları, 270 s., ISBN: 978-605-2338-37-7
}

Metehan INANÇ**

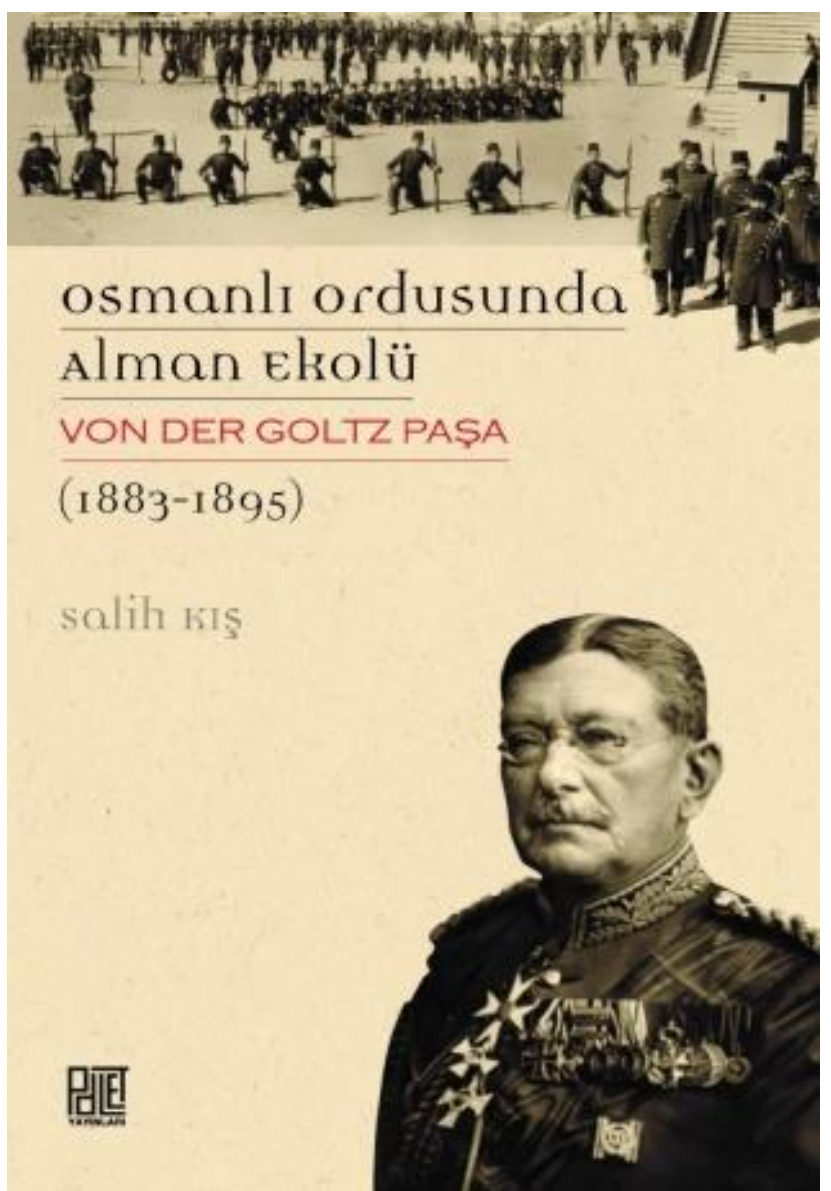

Genel çalışmaları XIX. yüzyıl Osmanlı maliyesi ve askerî teşkilatı üzerine olan Salih Kış, Selçuk Üniversitesindeki eğitimi sonrası akademik hayata atılmıştır. Hâlen Selçuk Üniversitesi Edebiyat Fakültesi Tarih Bölümünde öğretim üyesi olarak görevine devam etmektedir.

Önsöz, teşekkür ve giriş ile başlayan eser üç bölümden oluşmaktadır. Birinci bölümde, Türk-Alman işbirliğinin başlangıç süreci, Alman askerî heyetinin çalışma kontratı ve çalışma süresi üzerinde durulmuştur. İkinci bölümde kitabın adı olan Von der Goltz Paşa'nın İstanbul'a gelmesi ve Osmanlı'daki askerî yükselişi hakkında bilgiler verilmiştir. Üçüncü bölümde ise Osmanlı ordu yapisinda Alman ekolünün askerî teşkilat ve nizamları, yapilan reformlar, Alman ordu yapısınin kısmen uygulanması tartışılmıştır. Osmanlı Ordusunda Alman Ekolü Von der Goltz Paşa adlı çalışma sonuç, bibliyografya, ekler ve dizin başlıkları ile son bulmuştur.

Kitabın birinci bölümünde Türk-Alman ilişkilerinin XV. yüzyıla kadar dayandığından bahsedilerek, iki ülke arasındaki ilk siyasi münasebetler üzerinde durulmuştur. Sultan III. Mustafa döneminde başlayan Osmanlı - Prusya ilişkileri ile Avrupa'dan örneklendirilen ordu modernleşmesinin başlamış olduğundan bahsedilmektedir. Osmanlı ordu modernleşmesi için istihdam edilen görevlilerin çalışmalarında başvurulan yollar anlatılmıştır. 1835-1839 yılları

\footnotetext{
Yüksek Lisans Öğrencisi, Selçuk Üniversitesi Sosyal Bilimler Enstitüsü Tarih Anabilim Dalı Atatürk İlkeleri ve İnkılap Tarihi Bilim Dall, e-posta: Metehan.inancc@gmail.com http://orcid.org/0000-0002-4537-8758
} 
arasında ordu modernizasyonu için gelen heyetten bahsedilerek bu heyetin Osmanlı'ya gelişi ve İstanbul'dan ayrılış sebepleri anlatılmıştır. Helmuth von Moltke'nin başkanlığını yaptığı bu heyete daha sonra çeşitli alanlarda başka subaylar eklenmiş ve bunların ismi kitapta tek tek verilmiştir. Kurulan numune alayları, Osmanlı ordusu için bütçe hazırlanması, düşük rütbeli subayların azlığı, bozuk ordu teşkilat yapısı gibi Osmanlı ordusunda görülen aksaklıklara da birinci bölümde değinilmiştir. Alman subayların Osmanlı Devleti ile yapmış oldukları kontratlar ve çalışma alanları ayrıntılı olarak anlatılmıştır.

Kitabın ikinci bölümünde ise Goltz Paşa'nın ordu modernizasyonu için davet edilme süreci ve Osmanlı askerî okulları genel müfettişliği tartışılmıştır. 1883-1895 yıllarını kapsayan Goltz Paşa'nın çalışma süresi boyunca yapılan kontratlar ayrıntılı olarak maddelendirilerek ele alınmıştır. İkinci bölümde, Goltz Paşa göreve gelmeden önceki durumlar ile geldikten sonraki Osmanlı ordu ve eğitim süreci karşılaştırılmıştır. Eğitimdeki Fransız ekolü bu dönemde yerini Alman ekolüne bırakmıştır. Askerî eğitimde ders programları, ders içerikleri Goltz Paşa'nın yaptığı reformlarla değişmiştir. Ayrıca, bu dönemde açılan askerî rüştiye okullarına ve yapısına değinilmiştir. Goltz Paşa'nın Erkan-ı Harbiye sınıfları için hazırladığı müfredat ve dersler tablo olarak gösterilmiştir. İlave olarak, 1888 yllında Harp Okulu'nda okutulan dersler ve eğitim kadrosu tablo olarak gösterilmiştir. Goltz Paşa'nın Fransızca kitaplar okutulmasına son vermek için bir komisyon kurup, uzun bir mesai sonrası "Erkan-ı Harbiye ve Muhtıra" isimli kitapları kendi yazdığını yine bu bölümde öğrenmekteyiz. Goltz Paşa'nın göreve başlamadan önce ve görev bitimindeki askerî öğrenci sayılarının karşılaştırılması ile de kısmen başarılı olduğunu yazar bize anlatmaktadır.

Kitabın son bölümü olan üçüncü bölümde ise Goltz Paşa'nın Osmanlı kara ordusunda gerçekleştirmeye çalıştığı ordu modernizasyonu ve Alman ordu modelinin uygulanışının kısmen başarıya ulaşması anlatılmaktadır. Bu bölümde XIX. yüzyıl ilk yarısından alınarak, Goltz Paşa göreve gelmeden önceki ordu teşkilat yapısı ele alınmaktadır. Böylece Goltz Paşa'nın kısmen başarılı olduğu alanlar okuyucunun konuyu daha iyi kavramasını sağlamaktadır. 1877 Salnamesi kaynak gösterilerek kurulan yedi ordu hakkında bize bilgi verilmektedir. Bu bölümde Osmanlı ordularında bulunan mektepli ve alaylı subayların rütbe, sayı ve okur-yazar durumları tablo ile gösterilmektedir. Goltz Paşa'nın yazdığı ve uygulamaya konulan kanunlardan Askere Alma Kanunu, Seferberlik Kanunu, Redif Kanunu ve Askeri Ceza Kanunu hakkında detaylı bilgiler verilmektedir. Yapılan reformların hayata konması için gerekli olan silah ve teçhizatın bulunması konusu ve bunun için Goltz Paşa'nın uğraşları yine üçüncü bölümde geçmektedir. Goltz Paşa döneminde Osmanlı ordusu için sipariş verilen "mavzer" adındaki silahların sayısı ve yıllara göre Osmanlıya gelişi tablolarla gösterilmiştir. Son olarak bu bölümde İstanbul'un muhafazası için alınması gereken savunma tedbirleri ve bu konuda Goltz Paşa'nın katkıları incelenmektedir. Goltz Paşa'nın boğazların tahkimi için yaptırdığ 1 krokiler ve haritalara da ayrı ayrı değinilmiştir.

Sonuç olarak ele aldığımızda, kitap bu alanda meraklı olan okurları belli bir noktaya taşıyabilecek düzeyde, yalın, anlaşılır ve dikkat çekici noktalara vurgu yapılarak kaleme alınmıştır. Salih Kış bu kitabında Osmanlı Ordu modernizasyonunu Goltz Paşa şahsında ayrıntılı bir şekilde incelemiştir. $\mathrm{Bu}$ incelemesinde Osmanlı - Prusya ilişkilerine, Osmanlı hizmetine giren Alman askerî uzmanlarına, II. Abdülhamit döneminde İstanbul'a gelen Alman askerî komisyonuna da ayrı ayrı yer vermiştir. Salih Kış, eserinde seçtiği örnekler ile Goltz Paşa'nın Osmanlı ordu modernizasyonunda faaliyetlerini daha anlaşılır kılmıştır. Eser sona erdikten sonra, Ekler kısmında karşımıza çıkan Paşa'nın kontrat metinleri, askerî komisyon belgeleri ve ders programları ile ilgili raporlar görsellerle sunulmuş, böylelikle konunun daha iyi anlaşılması sağlanmıştır. Türk ve Alman arşivlerinden yararlanılarak hazırlanan bu eserde 
döneme ait süreli yayınlar, yıllıklar, devlet eliyle düzenlenen layihalar ve nizamnameler de kullanılmıştır. Son olarak eser Osmanlı askerî teşkilatı üzerine çalışacak ve araştırma yapacak kişiler için önemli bir kaynak konumundadır. 